\title{
Influence of corm size and spacing on growth and yield of gladiolus under Nilgiris condition
}

\author{
V Deepashree, M Ganga,S Karthikeyan \& B Anitha
}

Journal of Agriculture and Ecology

ISSN: 2456-9410

Volume: 7

Journal of Agriculture and Ecology (2019) 7: 47-54

http://doi.org/10.53911/JAE.2019.7105

Volume-7 (June, 2019) ISSN: $2456-9410$

\section{Journal of Agriculture and Ecology}




\title{
Influence of corm size and spacing on growth and yield of gladiolus under Nilgiris condition
}

\author{
V Deepashree $\mathbb{Z}^{*}$, M Ganga, S Karthikeyan \& B Anitha \\ Tamil Nadu Agricultural University, Tamil Nadu (India) \\ X Corresponding author:V Deepashree,E-mail: itisdeepthi@gmail.com
}

\section{Article Info}

Article history

Received: 18 April 2019

Accepted: 15 May 2019

Available online: 15 June 2019

Key Words: Gladiolus, corm size, spacing, spike quality.

\begin{abstract}
Gladiolus is one of the most popular ornamental bulbous plants grown in many parts of the world as cut flower and bedding plant for its bewitching flowers. It is an emerging cut flower with enormous potential to be used extensively. The present study was conducted to standardize corm size and spacing in order to obtain quality produce to meet the quality standards. The corms of gladiolus cv. White Prosperity of three size group (01-10, 11-20, $21-30 \mathrm{~g})$ were planted in three spacing $\left(40 \times 20,30 \times 30,30 \times 20 \mathrm{~cm}^{2}\right)$ and data were recorded on vegetative, flowering and corm production. The research revealed the days taken for $80 \%$ emergence of the crop, plant height at flowering $(\mathrm{cm})$, leaf length at flowering $(\mathrm{cm})$, rachis length $(\mathrm{cm})$, floret length $(\mathrm{cm})$, number of florets/ spike, no. of corms/plant, average corm weight $(\mathrm{g})$, average corm diameter $(\mathrm{cm})$ were found superior in gladiolus corm of size 21-30 g planted at a spacing of $40 \times 20 \mathrm{~cm}^{2}$ under Nilgiris condition.
\end{abstract}

Copyright (C2019 Deepashree et al., This is an open access article published under the terms of the Creative Commons Attribution License, which permits unrestricted use, distribution, and reproduction in any medium, provided the original work is properly cited.

Preferred citation: Deepashree V, Ganga M, Karthikeyan S \& Anitha B. 2019. Influence of corm size and spacing on growth and yield of gladiolus under Nilgiris condition. Journal of Agriculture and Ecology, 7: 47-54; http://doi.org/10.53911/JAE.2019.7105.

\section{Introduction}

Gladiolus a popular bulbous cut flower belongs to the family Iridaceae with 255 species. It is one of the most popular ornamental bulbous plants grown in many parts of the world as cut flower and bedding plant for its bewitching flowers. It occupies a significant position in the international cut flower trade. The Gladiolus cv. White Prosperity posses sword shaped leaves with thickened margins and midrib. In India gladiolus is grown in an area of about 11,660 ha with an estimated production of 106 crore cut flowers. Amongst the cut flowers, gladiolus occupied third position in terms of both area and production. In India, major gladiolus producing states are Uttar Pradesh, West Bengal, Odisha, Chhattisgarh, Haryana \& Maharashtra. Gladiolus is also grown in states like Uttarakhand, Karnataka, Andhra Pradesh and Sikkim. 
Even though gladiolus is mainly a winter season flower crop, in areas having moderate climatic conditions, gladiolus can be grown throughout the year (NABARD 2016). The quality of spikes, productivity, corms and cormels produced are known to influence by several factors such as cultivar, nutrition and plant density and size of the planting material. Thus, the present study was undertaken with the aim of optimizing two important requirements for commercial cultivation viz., corm size and plant spacing for cultivation of gladiolus in the Nilgiris district of Tamil Nadu. Owing to the prevalence of sub temperate climate in the Nilgiris of Tamil Nadu attempts are in process for the commercialization of gladiolus production in Tamil Nadu.

\section{Materials and Methods}

The experimental site was located at Woodhouse Farm of Horticultural Research Station, Ooty at an altitude of 2,500 $\mathrm{m}$ at altitude. The location is found under average climatic condition of 15 to $17^{\circ} \mathrm{C}$ with a relative humidity of 80 to 85 per cent during the experimental period. The experiment was carried out in Factorial Randomized Block Design (FRBD) with 2 factors at 3 level each viz., $1^{\text {st }}$ factor - corm size (1-10, 11-20 and 21$30 \mathrm{~g})$ and $2^{\text {nd }}$ factor - spacing $(40 \times 20,30 \times$ $30,30 \times 20 \mathrm{~cm}^{2}$ ), respectively. The corms were uniformly planted at a depth of $5 \mathrm{~cm}$ during the month of November 2017 which were treated with ethrel at $100 \mathrm{ppm}$. Observations were recorded on the vegetative and yield and corm parameters during flowering stage. The recorded observation were analyzed statistically with AGRES software package, MS excel spreadsheet.

\section{Results and Discussion}

\section{Vegetative characters}

The data pertaining to the effect of corm size and spacing on vegetative parameters are presented in Table.1. The results clearly indicated a significant influence of corm size and spacing on days taken for $80 \%$ emergence of the crop. It was found as the corm size and spacing increases the days taken for sprouting decreases. The $80 \%$ emergence of the crop found earlier flowering in large corms (21-30 g) in 23.97 days and wider spacing of $(40 \times 20 \mathrm{~cm}) 23.96$ days and delayed emergence was recorded in small corms (01-10 g) 27.04 days and narrow spacing of $(30 \times 20 \mathrm{~cm}) 27.13$ days was recorded. On interaction large corms (21-30 g) planted at the widest spacing $(40 \times 20 \mathrm{~cm})$ recorded the earliest sprouting 23.65 days which was found to be on par with large corms at medium spacing $(30 \times 30 \mathrm{~cm}) 23.73$ days against the small corms (01-10 g) planted at the narrowest spacing $(30 \mathrm{x} 20 \mathrm{~cm})$ recorded the most delayed sprouting of 29.40 days.

The maximum plant height was recorded in large corms $(21-30 \mathrm{~g}) 96.52 \mathrm{~cm}$ and wider spacing at $(40 \times 20 \mathrm{~cm}) 96.03 \mathrm{~cm}$ and minimum plant height was recorded in small corms $(01-11 \mathrm{~g})$ at $86.24 \mathrm{~cm}$ and at narrow spacing of $(30 \times 20 \mathrm{~cm}) 89.17 \mathrm{~cm}$, where on interaction maximum plant height was recorded in large corms (21-30 g) planted at the widest spacing $(40 \times 20 \mathrm{~cm})$ as 101.24 
$\mathrm{cm}$ followed by large size corm (21-30 g) with medium spacing $(30 \times 30 \mathrm{~cm})$ of $97.31 \mathrm{~cm}$ and the smallest corms $(01-10 \mathrm{~g})$ planted at the narrowest spacing $(30 \times 20 \mathrm{~cm})$ recorded the minimum plant height of $81.23 \mathrm{~cm}$.

The maximum leaf length was recorded in large corms $(21-30 \mathrm{~g})$ of $35.85 \mathrm{~cm}$ and widest spacing $(40 \times 20 \mathrm{~cm})$ of $35.45 \mathrm{~cm}$ and the minimum leaf length was recorded in small corms (01-11 g) $29.02 \mathrm{~cm}$ and narrow spacing of $(30 \times 20 \mathrm{~cm})$ as $29.69 \mathrm{~cm}$. On interaction the maximum leaf length was recorded in large corms (21-30 g) planted at the widest spacing $(40 \times 20 \mathrm{~cm})$ recorded the $37.89 \mathrm{~cm}$ followed by large size corm (21-30 g) with medium spacing of $(30 \times 30 \mathrm{~cm})$ of $35.89 \mathrm{~cm}$ which was found to be on par with medium size corm (11-20 g) planted at wider spacing of (40 x $20 \mathrm{~cm}) 35.37 \mathrm{~cm}$ and the smallest corms (01-10 g) planted at the narrowest spacing (30 $\mathrm{x} 20 \mathrm{~cm}$ ) recorded the minimum leaf length of $25.44 \mathrm{~cm}$.

Large corm size directly influences the acceleration of growth of the plants which results in earlier sprouting of corms that attributes to the higher quantity of reserve food materials in the corm. Under wider spacing the competition between the plants for nutrients and light is comparatively less and hence the decline in growth under lesser spacing may be due to higher competition of plants for soil, nutrient and other factors. These results were found to similar with the work done by Mollah et al. (1995) and Kareem et al. (2013) in gladiolus (Table.1)

\section{Floral characters}

Flower quality was also significantly influenced by corm size and spacing and the data is presented in Table 2. The maximum rachis length was recorded in medium corms (11-20 g) of $42.65 \mathrm{~cm}$ and widest spacing of $(40 \times 20 \mathrm{~cm}) 44.57 \mathrm{~cm}$ and the minimum rachis length was recorded in large corms of (21-30 g) $41.19 \mathrm{~cm}$ and medium spacing of $(30 \times 30 \mathrm{~cm}) 41.44 \mathrm{~cm}$. On interaction the maximum rachis length was recorded in large corms (21-30 g) planted at the widest spacing $(40 \times 20 \mathrm{~cm})$ of $45.43 \mathrm{~cm}$ which was on par with medium sized corm (11-20 g) planted at widest spacing of $(40 \times 20 \mathrm{~cm}) 45.20 \mathrm{~cm}$ and the medium sized corms $(11-21 \mathrm{~g})$ planted at the medium spacing $(30 \times 30 \mathrm{~cm})$ recorded the minimum rachis length of $40.67 \mathrm{~cm}$.

Floret length was found to be maximum in large sized corm (21-30 g) of $9.41 \mathrm{~cm}$ and in widest spacing $(40 \times 20 \mathrm{~cm})$ of $9.44 \mathrm{~cm}$ and the minimum floret length was found in small corms of $(01-11 \mathrm{~g}) 8.88 \mathrm{~cm}$ and narrow spacing of $(30$ x $20 \mathrm{~cm}) 8.83 \mathrm{~cm}$, whereas the interactions between the spacing and the corm size were not found to be significant in floret length of Gladiolus cv. White Prosperity. The chance for availability is higher which enhances the growth and yield. The maximum number of florets / spike was recorded in large corms of (21-30 g) 14.31 and widest spacing of $(40 \times 20 \mathrm{~cm})$ 14.66 and the minimum number of florets / spike was recorded in small corms of (01-10 g) 10.35 and narrow spacing of $(30 \times 20 \mathrm{~cm})$ 10.32. On interaction the maximum number of florets / spike was recorded in large corms of (21-30 g) planted at the widest spacing (40 x $20 \mathrm{~cm}$ ) of 16.66 followed by large sized corm 
(21-30 g) planted at medium spacing of $(30 \mathrm{x}$ $30 \mathrm{~cm}$ ) recorded 14.65 which was on par with medium sized corms (11-20 g) planted at widest spacing of $(40 \times 20 \mathrm{~cm}) 14.63$ and the minimum number of florets / spike was recorded in small corm (01-11 g) planted at narrow spacing of $(30 \times 20 \mathrm{~cm})$ 8.67. the enhanced quality parameter of flower were found in plants from larger corms planted at wider spacing which might be due to less competition between plants for water, mineral, nutrition and light enabling favourable photosynthesis and translocation of assimilates to the reproductive organs coupled with synthesis of growth hormones leading to production of longer flower spikes. The results were found to be in consonance with Bisen (2013).

\section{Corm parameters}

The results pertaining to corm parameter are presented in Table 3, which indicated a significant influence of corm size and spacing on maximum number of corms / plant was recorded in large corms (21-30 g) of 1.88 and wider spacing $(40 \times 20 \mathrm{~cm})$ of 1.76 and minimum number of corms / plant was recorded in small corms (01-10 g) of 1.31 and the narrow spacing of $(30 \times 20 \mathrm{~cm}) 1.34$. On interaction maximum number of corms / plant was recorded in large corms (21-30 g) planted at the widest spacing $(40 \times 20 \mathrm{~cm})$ of 2.01 followed by large sized corm (21-30 g) planted at medium spacing of $(30 \times 30 \mathrm{~cm})$ recorded 1.91 and the minimum number of corms were recorded in small sized corms (01$10 \mathrm{~g})$ planted at narrow spacing $(30 \times 20 \mathrm{~cm})$ of 1.01 .
The average corm weight was recorded higher in large corms (21-30 g) of 22.08 $\mathrm{g}$ and widest spacing of $(40 \times 20 \mathrm{~cm}) 21.33$ and average corm weight was recorded lower corm weight was recorded in small corms (01$10 \mathrm{~g})$ of $12.33 \mathrm{~g}$ and narrow spacing of $(40 \mathrm{x}$ $20 \mathrm{~cm}) 12.86 \mathrm{~g}$, in case of interaction the average corm weight was recorded higher in large corms (21-30 g) planted at the widest spacing $(40 \times 20 \mathrm{~cm})$ of $30.16 \mathrm{~g}$ followed by medium sized corm (11-20 g) planted at widest spacing of $(40 \times 20 \mathrm{~cm})$ recorded 27.10 $\mathrm{g}$ and the minimum weight of corms were recorded in small sized corms (01-10 g) planted at widest spacing $(40 \times 20 \mathrm{~cm})$ of 6.73 g. The average corm diameter was recorded higher in large corms (21-30 g) of $4.82 \mathrm{~cm}$ and widest spacing of $(40 \times 20 \mathrm{~cm})$ $5.13 \mathrm{~cm}$ and minimum corm diameter was recorded in small corms $(01-11 \mathrm{~g})$ of $3.85 \mathrm{~cm}$ and narrow spacing of $(30 \times 20 \mathrm{~cm}) 3.40 \mathrm{~cm}$, whereas on interaction the average corm diameter was recorded higher in large corms (21-30 g) planted at the widest spacing (40 x $20 \mathrm{~cm}$ ) of $5.70 \mathrm{~cm}$ followed by medium sized corm (11-20 g) planted at widest spacing of $(40 \times 20 \mathrm{~cm})$ of 5.14 and the minimum diameter of corms were recorded in small sized corms (01-10 g) planted at widest spacing $(40 \times 20 \mathrm{~cm})$ of $3.18 \mathrm{~cm}$. This might be due to the fact that higher the larger mother corms planted at wider spacing might have enhanced the rate of photosynthesis followed by subsequent translocation of assimilates to the storage organs. These observations are supported by earlier reports on gladiolus by Kumar et al. (2016) and Ahmed et al. (2010) wherein wider spaced plants produced corms with greater diameter. 
Table 1. Effect of corm size and plant spacing on vegetative parameters in Gladiolus cv. white prosperity

\begin{tabular}{|c|c|c|c|c|c|c|c|c|c|c|c|c|}
\hline \multirow{2}{*}{$\begin{array}{l}\quad \text { Treatment } \\
\text { Corm } \\
\text { Size \& Spacing }\end{array}$} & \multicolumn{4}{|c|}{$\begin{array}{c}\text { Days taken for } 80 \% \text { emergence of the } \\
\text { crop }\end{array}$} & \multicolumn{4}{|c|}{ Plant height at flowering $(\mathrm{cm})$} & \multicolumn{4}{|c|}{ Leaf length at flowering $(\mathrm{cm})$} \\
\hline & $\begin{array}{c}\mathrm{C}_{1} \\
\text { Large } \\
(21-30 \mathrm{~g})\end{array}$ & $\begin{array}{c}\mathrm{C}_{2} \\
\text { Medium } \\
(11-20 \mathrm{~g})\end{array}$ & $\begin{array}{c}\mathrm{C}_{3} \\
\text { Small } \\
(01-10 \mathrm{~g})\end{array}$ & Mean & $\begin{array}{c}\mathrm{C}_{1} \\
\text { Large } \\
(21-30 \mathrm{~g})\end{array}$ & $\begin{array}{c}\mathrm{C}_{2} \\
\text { Medium } \\
(11-20 \mathrm{~g})\end{array}$ & $\begin{array}{c}\mathrm{C}_{3} \\
\text { Small } \\
(01-10 \mathrm{~g})\end{array}$ & Mean & $\begin{array}{c}\mathrm{C}_{1} \\
\text { Large } \\
(21-30 \mathrm{~g})\end{array}$ & $\begin{array}{c}\mathrm{C}_{2} \\
\text { Medium } \\
(11-20 \mathrm{~g})\end{array}$ & $\begin{array}{c}\mathrm{C}_{3} \\
\text { Small } \\
(01-10 \mathrm{~g})\end{array}$ & Mean \\
\hline $\mathrm{S}_{1}: 40 \times 20 \mathrm{~cm}$ & 23.65 & 24.11 & 24.14 & 23.96 & 101.24 & 95.61 & 91.25 & 96.03 & 37.89 & 35.37 & 33.11 & 35.45 \\
\hline $\mathrm{S}_{3}: 30 \times 20 \mathrm{~cm}$ & 24.54 & 27.44 & 29.40 & 27.13 & 91.03 & 95.25 & 81.23 & 89.17 & 33.77 & 29.86 & 25.44 & 29.69 \\
\hline \multirow[t]{2}{*}{ Mean } & 23.97 & 25.66 & 27.04 & 25.56 & 96.52 & 93.70 & 86.24 & 92.16 & 35.85 & 32.14 & 29.02 & 32.34 \\
\hline & $\mathrm{SE}(\mathrm{d})$ & $\begin{array}{c}\text { CD } \\
(0.05)\end{array}$ & $\begin{array}{c}\text { CD } \\
(0.01)\end{array}$ & & $\mathrm{SE}(\mathrm{d})$ & $\begin{array}{c}\mathrm{CD} \\
(0.05)\end{array}$ & $\begin{array}{c}\text { CD } \\
(0.01)\end{array}$ & & $\mathrm{SE}(\mathrm{d})$ & $\begin{array}{c}\text { CD } \\
(0.05)\end{array}$ & $\begin{array}{c}\text { CD } \\
(0.01)\end{array}$ & \\
\hline Corm size (C) & 0.34 & 0.72 & 0.99 & & 0.93 & 1.98 & 2.73 & & 0.45 & 0.96 & 1.32 & \\
\hline $\begin{array}{l}\text { Interaction } \\
\quad(\mathrm{S} \times \mathrm{C})\end{array}$ & 0.59 & 1.25 & 1.72 & & 1.62 & 3.44 & 4.74 & & 0.78 & 1.66 & 2.29 & \\
\hline
\end{tabular}




\section{Journal of Agriculture and Ecology, 2019, Vol.7, 47-54}

http://saaer.org.in

Table 2. Effect of corm size and plant spacing on floral parameters in Gladiolus cv. white prosperity

\begin{tabular}{|c|c|c|c|c|c|c|c|c|c|c|c|c|}
\hline \multirow{2}{*}{$\begin{array}{l}\quad \text { Treatment } \\
\text { Corm } \\
\text { Size \& Spacing }\end{array}$} & \multicolumn{4}{|c|}{ Rachis length $(\mathrm{cm})$} & \multicolumn{4}{|c|}{ Floret length (cm) } & \multicolumn{4}{|c|}{ Number of florets/ spike } \\
\hline & $\begin{array}{c}\mathrm{C}_{1} \\
\text { Large } \\
(21-30 \mathrm{~g})\end{array}$ & $\begin{array}{c}\mathrm{C}_{2} \\
\text { Medium } \\
(11-20 \mathrm{~g})\end{array}$ & $\begin{array}{c}\mathrm{C}_{3} \\
\text { Small } \\
(01-10 \mathrm{~g})\end{array}$ & Mean & $\begin{array}{c}\mathrm{C}_{1} \\
\text { Large } \\
(21-30 \mathrm{~g})\end{array}$ & $\begin{array}{c}\mathrm{C}_{2} \\
\text { Medium } \\
(11-20 \mathrm{~g})\end{array}$ & $\begin{array}{c}\mathrm{C}_{3} \\
\text { Small } \\
(01-10 \mathrm{~g})\end{array}$ & Mean & $\begin{array}{c}\mathrm{C}_{1} \\
\text { Large } \\
(21-30 \mathrm{~g})\end{array}$ & $\begin{array}{c}\mathrm{C}_{2} \\
\text { Medium } \\
(11-20 \mathrm{~g})\end{array}$ & $\begin{array}{c}\mathrm{C}_{3} \\
\text { Small } \\
(01-10 \mathrm{~g})\end{array}$ & Mean \\
\hline $\mathrm{S}_{1}: 40 \times 20 \mathrm{~cm}$ & 45.43 & 45.20 & 43.09 & 44.57 & 9.67 & 9.41 & 9.26 & 9.44 & 16.66 & 14.63 & 12.38 & 14.66 \\
\hline $\mathrm{S}_{3}: 30 \times 20 \mathrm{~cm}$ & 41.19 & 40.67 & 42.77 & 41.54 & 9.13 & 8.87 & 8.51 & 8.83 & 11.31 & 10.98 & 8.67 & 10.32 \\
\hline \multirow[t]{2}{*}{ Mean } & 41.19 & 42.65 & 42.31 & 42.52 & 9.41 & 9.15 & 8.88 & 9.15 & 14.31 & 12.65 & 10.35 & 12.44 \\
\hline & $\mathrm{SE}(\mathrm{d})$ & $\begin{array}{c}\text { CD } \\
(0.05)\end{array}$ & $\begin{array}{c}\text { CD } \\
(0.01)\end{array}$ & & $\mathrm{SE}(\mathrm{d})$ & $\begin{array}{c}\text { CD } \\
(0.05)\end{array}$ & $\begin{array}{c}\text { CD } \\
(0.01)\end{array}$ & & $\mathrm{SE}(\mathrm{d})$ & $\begin{array}{c}\text { CD } \\
(0.05)\end{array}$ & $\begin{array}{c}\text { CD } \\
(0.01)\end{array}$ & \\
\hline $\begin{array}{l}\text { Interaction } \\
\quad(\mathrm{S} \times \mathrm{C})\end{array}$ & 0.88 & 1.87 & 2.58 & & NS & NS & NS & & 0.27 & 0.58 & 0.79 & \\
\hline
\end{tabular}


Table 3. Effect of corm size and plant spacing on corm parameters in Gladiolus cv. white prosperity

\begin{tabular}{|c|c|c|c|c|c|c|c|c|c|c|c|c|}
\hline \multirow{2}{*}{$\begin{array}{l}\text { Treatment } \\
\text { Corm size } \\
\text { Spacing }\end{array}$} & \multicolumn{4}{|c|}{ No. of corms/plant } & \multicolumn{4}{|c|}{ Average corm weight (g) } & \multicolumn{4}{|c|}{ Average corm diameter $(\mathrm{cm})$} \\
\hline & $\begin{array}{c}\mathrm{C}_{1} \\
\text { Large } \\
(21-30 \mathrm{~g})\end{array}$ & $\begin{array}{c}\mathrm{C}_{2} \\
\text { Medium } \\
(11-20 \mathrm{~g})\end{array}$ & $\begin{array}{c}\mathrm{C}_{3} \\
\text { Small } \\
(01-10 \mathrm{~g})\end{array}$ & Mean & $\begin{array}{c}\mathrm{C}_{1} \\
\text { Large } \\
(21-30 \mathrm{~g})\end{array}$ & $\begin{array}{c}\mathrm{C}_{2} \\
\text { Medium } \\
(11-20 \mathrm{~g})\end{array}$ & $\begin{array}{c}\mathrm{C}_{3} \\
\text { Small } \\
(01-10 \mathrm{~g})\end{array}$ & Mean & $\begin{array}{c}\mathrm{C}_{1} \\
\text { Large } \\
(21-30 \mathrm{~g})\end{array}$ & $\begin{array}{c}\mathrm{C}_{2} \\
\text { Medium } \\
(11-20 \mathrm{~g})\end{array}$ & $\begin{array}{c}\mathrm{C}_{3} \\
\text { Small } \\
(01-10 \mathrm{~g})\end{array}$ & Mean \\
\hline $\begin{array}{c}\mathrm{S}_{1}: 40 \times 20 \\
\mathrm{~cm}\end{array}$ & 2.01 & 1.71 & 1.56 & 1.76 & 30.16 & 27.10 & 6.73 & 21.33 & 5.70 & 5.01 & 4.59 & 5.13 \\
\hline $\begin{array}{c}\mathrm{S}_{2}: 30 \times 30 \\
\mathrm{~cm}\end{array}$ & 1.91 & 1.57 & 1.37 & 1.61 & 21.40 & 19.59 & 18.73 & 19.90 & 5.14 & 4.41 & 3.80 & 4.45 \\
\hline $\begin{array}{c}\mathrm{S}_{3}: 30 \times 20 \\
\mathrm{~cm}\end{array}$ & 1.73 & 1.30 & 1.01 & 1.34 & 14.70 & 12.37 & 11.53 & 12.86 & 3.62 & 3.41 & 3.18 & 3.40 \\
\hline \multirow[t]{2}{*}{ Mean } & 1.88 & 1.52 & 1.31 & 1.57 & 22.08 & 19.68 & 12.33 & 18.03 & 4.82 & 4.30 & 3.85 & 4.32 \\
\hline & $\mathrm{SE}(\mathrm{d})$ & $\begin{array}{c}\text { CD } \\
(0.05)\end{array}$ & $\begin{array}{c}\text { CD } \\
(0.01)\end{array}$ & & $\mathrm{SE}(\mathrm{d})$ & $\begin{array}{l}\text { CD } \\
(0.05)\end{array}$ & $\begin{array}{c}\text { CD } \\
(0.01)\end{array}$ & & $\mathrm{SE}(\mathrm{d})$ & $\begin{array}{c}\text { CD } \\
(0.05)\end{array}$ & $\begin{array}{c}\text { CD } \\
(0.01)\end{array}$ & \\
\hline Spacing $(\mathrm{S})$ & 0.02 & 0.04 & 0.06 & & 0.23 & 0.49 & 0.68 & & 0.04 & 0.10 & 0.14 & \\
\hline $\begin{array}{l}\text { Corm size } \\
\text { (C) }\end{array}$ & 0.02 & 0.04 & 0.06 & & 0.23 & 0.49 & 0.68 & & 0.04 & 0.10 & 0.14 & \\
\hline $\begin{array}{l}\text { Interaction } \\
\quad(\mathrm{S} \times \mathrm{C})\end{array}$ & 0.03 & 0.08 & 0.11 & & 0.40 & 0.85 & 1.18 & & 0.08 & 0.18 & 0.24 & \\
\hline
\end{tabular}




\section{Conclusions}

From the results of the experiment, it has been found that large corm (21-30 g corm weight) planted at a spacing of $40 \times 20 \mathrm{~cm}$ resulted in the earliest corm sprouting (23.65 days for $80 \%$ sprouting), maximum plant height at flowering $(101.24 \mathrm{~cm})$, highest number of florets/spike (16.66) and higher number of corms (2.01) in Gladiolus cv. White Prosperity. Thus it can be concluded that widest spacing and larger the corm size, gives a potential increase in yield and it is recommended for the growers in the Nilgiris district for higher benefit and production of quality produce.

\section{Reference}

Ahmed MJ, Ahmad M, Bashir T, Yaqoob A, Jillani MS \& Saeed M. 2010. Effect of plant spacing on vegetative and reproductive growth of gladiolus cultivars, Sarhad Journal of Agriculture, 26(4): 539-544.
Bisen Y. 2013. Effect of corm size and spacing on growth, flowering and yield attributes of Gladiolus, Asian Journal of Horticulture, 8(1): 230-233.

Kareem A, Khan MA \& Afzal I. 2013. Different corm sizes affect performance of Gladiolus grandiflorus Cv. Red Majesty and Early Yellow. Advances in Zoology and Botany, 1(4): 86-91.

Kumar K, Singh CN, Beniwal VS \& Pinder R. 2016. Effect of Spacing on Growth , Flowering and Corm Production of Gladiolus ( Gladiolus sp .) cv . American Beauty, 2(3): 550-554.

Mollah MS, Islam S, Rafiuddin M, Choudhury SS \& Saha SR. 1995. Effect of Cormel Size and Spacing on Growth and Yield of Flower and Corm of Gladiolus. Bangladesh Horticulture, 23(1\&2): 67-71. 